\title{
UJI EFEKTIVITAS BEBERAPA KONSENTRASI EKSTRAK DAUN KETAPANG (Terminalia catappa L.) TERHADAP ULAT GRAYAK (Spodoptera litura) SECARA IN VITRO
}

\section{Test Effectiveness of Some Ketapang Leaf Extract Concentration (Terminalia catappa L.) to Grayak Caterpillars (Spodoptera litura) In Vitro}

\author{
Riski Nella Sari Batubara, Yusmar Mahmud, Rita Elfianis \\ Laboratorium Patologi Entomologi dan Patologi, Fakultas Pertanian dan Peternakan \\ Universitas Islam Negeri Sultan Syarif Kasim Riau \\ Email: riskinella.batubara@gmail.com \\ [Diterima: Februari 2021; Disetujui: April 2021]
}

\begin{abstract}
Spodoptera litura is one of the important plant pests that are polyphagic. Spodoptera litura attacks can cause damage to up $80 \%$ on plants causing losses for framer. Control using synthetic pesticides is excessive because it causes negative for environment. Efforts that can be made are using biopesticides such as Terminalia catappa L. leaves. This research aims to obtain effective concentrations in controlling Spodoptera litura in vitro. The research was carried out in Pathology, Entomology and Microbiology, Faculty of Agriculture and Animal Husbandry and experimental farm of State Islamic University of Sultan Syarif Kasim from February to March 2019. This research used a Completely Randomized Design with 5 treatments, consisting of control, 9\% EDK, 18\% EDK, 27\% EDk and 36\% EDK with 3 replications. The parameters used are larvae stop eating (\%), speed of death, mortality, toxicity of $\mathrm{LC}_{50}$ and larvae become pupae (\%). The result showed the effective concentration in controlling Spodoptera litura was EDK 18\%.
\end{abstract}

Keywords: Terminalia catappa L., Effectiveness, Spodoptera litura

\begin{abstract}
ABSTRAK
Ulat grayak (Spodoptera litura) merupakan salah satu hama tanaman penting yang bersifat polifag dan dapat menyebabkan kerusakan hingga mencapai $80 \%$ pada tanaman, sehingga merugikan petani. Pengendalian menggunakan pestisida sintetik yang berlebihan menyebabkan terjadinya dampak negatif bagi lingkungan. Upaya yang dapat dilakukan adalah dengan penggunaan pestisida nabati seperti daun ketapang (Terminalia catappa L.). Penelitian ini bertujuan untuk mendapatkan konsentrasi ekstrak daun ketapang yang efektif dalam mengendalikan hama Spodoptera litura secara in vitro. Penelitian dilakukan di laboratorium Patologi, Entomologi dan Mikrobiologi, Fakultas Pertanian dan Peternakan dan lahan percobaan Universitas Islam Negeri Sultan Syarif Kasim Riau pada bulan Februari hingga Maret 2019. Penelitian menggunakan Rancangan Acak Lengkap dengan 5 perlakuan yang terdiri dari kontrol, 9\% EDK, 18\% EDK, 27\% EDK dan 36\% EDK dengan masingmasing 3 ulangan. Parameter yang digunakan yaitu larva bergenti makan (\%), kecepatan kematian, mortalitas, toksisitas $\mathrm{LC}_{50}$ dan larva menjadi pupa (\%). Berdasarkan hasil penelitian disimpulkan bahwa konsentrasi efektif adalah konsentrasi EDK 18\%
\end{abstract}

Kata kunci: Ketapang, Efektivitas, Spodoptera litura

\section{PENDAHULUAN}

Ulat grayak (Spodoptera litura) merupakan salah satu jenis hama penting yang menyerang tanaman palawija dan sayuran di Indonesia. Hama ini sering menyebabkan penurunan produktivitas bahkan kegagalan panen karena menyebabkan daun dan buah berlubang. Spodoptera litura bersifat polifag atau dapat menyerang berbagai jenis tanaman pangan, sayuran dan buah-buahan. Serangan Spodoptera litura pada fase instar 1-3 ditandai dengan habisnya lapisan epidermis daun sehingga daun menjadi transfaran. Sedangkan pada fase instrar 4-5 ditandai dengan daun yang menjadi bolong. 
Serangan instar Spodoptera litura tentunya akan menyebabkan terganggunya proses fotosintesis pada tanaman sehingga dapat menyebabkan kematian. Kehilangan hasil akibat serangan hama tersebut dapat mencapai $80 \%$ jika tidak dikendalikan. Gejala serangan yang cepat dan susah dikendalikan inilah menyebabkan perlunya pengendalian yang intensif (Marwoto dan Suharsono, 2008).

Pengendalian hama tanaman tidak langsung dapat meningkatkan hasil, namun membatasi kehilangan potensi hasil yang diusahakan dengan intensifikasi. Sampai saat ini petani mengendalikan hama Spodoptera litura pada umumnya menggunakan pestisida kimia secara intensif. Mengingat dampak negatif yang ditimbulkan dari penggunaan pestisida kimia banyak sekali baik itu untuk lingkungan maupun bagi manusia maka dilakukan alternatif pengendalian lain yaitu dengan pemanfaatan bahan-bahan alam sebagai biopestisida (Samsudin, 2008).

Biopestisida secara umum diartikan sebagai pestisida yang bahan aktifnya berasal dari tanaman yang kaya bahan aktif. Kardinan (2002), tanaman yang dapat digunakan sebagai bahan insektisida alami adalah semua tanaman yang mengandung bahan kimia saponin, sianida, flavonoid, tannin, steroid dan minyak atsiri. Salah satu tanaman yang dapat dimanfaatkan sebagai pestisida nabati adalah ketapang (Terminalia catappa L.). Irnawati dan Nita (2012), beberapa kandungan alami yang terkandung dalam daun ketapang maupun buah yaitu flavanoid, alkaloid, tanin dan fenolik, saponin dan terpenoid.

\section{METODE PENELITAN}

Penelitian ini telah dilakukan di Laboratorium Patologi, Entomologi dan Mikrobiologi (PEM) dan kebun percobaan Universitas Islam Negeri Sultan Syarif Kasim Riau, pada bulan Februari sampai Maret 2019.

Alat yang digunakan: cangkul, blender, botol plastik, toples, kain kasa, gelas ukur, timbangan, gunting dan saringan dan pisau. Sedangkan bahan yang digunakan: Spodoptera litura, bibit kacang kedelai, daun ketapang, sarung tangan, masker, kertas label, tanah, polibag, pupuk kandang, madu, metanol 96\% dan air.

Penelitian ini menggunakan Rancangan Acak Lengkap (RAL) non faktorial yang terdiri dari 5 perlakuan dengan ulangan masing-masing 3. Pada penelitian ini dilakukan metode pengeceran konsentrasi ekstrak daun ketapang dengan rumus:

\section{$\mathrm{C} 1 \mathrm{~V} 1=\mathrm{C} 2 \mathrm{~V} 2$}

Keterangan:

$\mathrm{C} 1=$ Konsentrasi larutan awal

$\mathrm{V} 1=$ Volume larutan awal

$\mathrm{C} 2=$ Konsetrasi larutan akhir

$\mathrm{V} 2=$ Volume larutan akhir

Sehingga didapatkan hasil sebagai berikut:

$\mathrm{P} 1=$ Kontrol

$\mathrm{P} 2=9 \%(90 \mathrm{ml} \mathrm{EDK}+81 \mathrm{ml}$ air $)$

$\mathrm{P} 3=18 \%(180 \mathrm{ml}$ EDK $+162 \mathrm{ml}$ air $)$

$\mathrm{P} 4=27 \%(270 \mathrm{ml}$ EDK $+243 \mathrm{ml}$ air $)$

$\mathrm{P} 5=36 \%$ (360 ml EDK $+324 \mathrm{ml}$ air $)$

\section{Pelaksanaan Penelitian}

1. Penyediaan pakan Spodoptera litura

yaitu menggunakan tanaman kacang kedelai yang ditanam sendiri sebelum penelitian. Bahan pakan berupa daun kacang kedelai diambil setelah tanaman kacang kedelai berumur 2 minggu. Pengambilan bahan pakan dilakukan dengan cara menggunting daun kedelai dari tangkai secara perlahan agar daun tetap utuh.

2. Pengumpulan dan perbanyakan Spodoptera litura dengan mencari di lahan-lahan pertanian. Pengumpulan Spodoptera litura sebagai bahan uji coba bisa dilakukan dengan cara mengumpulkan telur maupun larva. Telur atau larva yang didapat

3. Pembuatan ekstrak daun ketapang yaitu dengan menggunakan daun muda berwarna hijau terang, tulang daun masih lembut dan daun bebas dari serangan hama atau penyakit sebanyak 500 g. Daun ketapang dicuci lebih dulu kemudian dicacah. Daun ketapang diblender dengan tambahan 500 $\mathrm{ml}$ air hingga halus sehingga didapatkan perbandingan 1:1,disaring untuk memisahkan cairan dengan ampas. Selanjutnya dilakukan penambahan larutan metanol $96 \%$ sebanyak $1.000 \mathrm{ml}$ selama 24 jam. Tohir (2010), pelarut yang baik untuk mengekstrak pestisida nabati adalah metanol dengan penurunan aktifitas makan rata-rata 41,30 .

4. Aplikasi ekstrak daun ketapang terhadap ulat grayak dilakukan satu hari setelah pembuatan ekstrak yaitu pada malam hari. Toples perlakuan yang telah berisi Spodoptera litura disusun sesuai dengan susunan yang telah ditentukan. Setiap 
toples perlakuan terdapat 10 helai daun kecang kedelai yang masih segar. Daun kacang kedelai pakan Spodopetra litura dicelupkan pada beberapa konsentrasi EDK yang telah ditentukan. Keringkan selama 2 menit. Daun yang telah kering dimasukkan ke dalam kemudian ditutup kembali dengan kain kasa. Pengamatan dilakukan selama 6 hari terhadap gejala fisik dan kematian ulat grayak setelah aplikasi EDK pada setiap parameter.

\section{HASIL DAN PEMBAHASAN}

\section{Larva Berhenti Makan (\%)}

Pengamatan larva berhenti makan pada penelitian dilakukan setiap 2 jam sekali selama 24 jam. Larva berhenti makan merupakan keadaan dimana larva uji coba tidak memakan daun bahan pakan setelah dilakukannya aplikasi ekstrak daun ketapang. Analisis sidik ragam Persentase larva berhenti makan selama 24 jam penelitian dapat dilihat pada Tabel 1 .

Tabel 1. Persentase Larva Berhenti Makan.

\begin{tabular}{cc}
\hline Perlakuan & $\begin{array}{c}\text { Persentase Larva } \\
\text { Berhenti Makan }(\%)\end{array}$ \\
\hline Kontrol & $0.00 \mathrm{~b}$ \\
$9 \%$ EDK & $11.11 \mathrm{ab}$ \\
$18 \%$ EDK & $22.22 \mathrm{a}$ \\
$27 \%$ EDK & $22.22 \mathrm{a}$ \\
$36 \%$ EDK & $22.22 \mathrm{a}$ \\
\hline
\end{tabular}

Harwanto, dkk., (2012) perbedaan tingkat konsentrasi tidak menyebabkan terjadinya perbedaan yang terlalu signifikan dalam penghambatan makan. Kandungan senyawa yang terdapat pada setiap konsentrasi perlakuan ekstrak menghasilkan efek yang sama yakni adanya perubahan bau, sehingga memicu larva tidak mampu untuk mengenali makanan. Secara bertahap larva akan mengalami perubahan perilaku yang menandakan larva berhenti makan.

Larva berhenti makan disebabkan oleh kandungan senyawa kimia yang terdapat pada ekstrak daun ketapang yang telah dianalisis. Senyawa kimia paling dominan dalam daun ketapang yaitu fenolik. Sejalan dengan penelitian Batubara, dkk. (2012) yang menyatakan bahwa fenolik sebagai larvasida bekerja dengan cara menekan konsumsi makan karena mengandung rasa pahit sehingga menyebabkan terhambat dan berkurangnya selera makan pada larva. Rasa pahit yang dihasilkan oleh kandungan senyawa tanin inilah yang berfungsi sebagai penolak makan pada larva sehingga larva berhenti memakan daun yang telah diaplikasikan dengan ektrak daun ketapang. Senyawa terpenoid merupakan salah satu senyawa yang bersifat sebagai antimakan (antifedant) karena rasanya yang pahit sehingga serangga menolak untuk makan. Larva yang telah berhenti makan ditandai dengan tidak adanya atau berkurangnya bekas gerekan pada permukaan daun oleh larva Spodoptera litura.

Larva yang telah berhenti makan juga menunjukkan perubahan yaitu gerakan menjadi lamban cenderung diam, ukuran tubuh larva yang menyusut baik itu berat maupun panjang larva, tubuh larva berubah warna dari hijau menjadi coklat kehitaman. Perubahan ini disebabkan oleh senyawa flavonoid yang menstimulasi kemoresptor kemudian dilanjutkan pada sistem saraf pusat serangga. Pada proses selanjutnya pengaruh zat dapat merusak jaringan tertentu yaitu organ pencernaan, kelenjar penghasil enzim atau jaringan saraf serangga (Yanuwadi, 2013).

\section{Kecepatan Kematian}

Setiap perlakuan pada penelitiam menyebabkan tingkat waktu kecepatan kematian larva yang berbeda dengan perlakuan lainnya. Penelitian dilakukan dengan mengamati dan menghitung tingkat kecepatan kematian terhadap larva yang diujikan. Jumlah kematian larva perhari akan dijumlahkan untuk mendapatkan persentase kematian larva. Hasil sidik ragam kecepatan kematian didapatkan bahwa kecepatan kematian seperti pada Tabel 2.

Tabel 2. Kecepatan Kematian.

\begin{tabular}{cc}
\hline Perlakuan & $\begin{array}{c}\text { Kecepatan Kematian } \\
(\%)\end{array}$ \\
\hline Kontrol & $0.00 \mathrm{~b}$ \\
$9 \%$ & $31.11 \mathrm{a}$ \\
$18 \%$ & $33.33 \mathrm{a}$ \\
$27 \%$ & $33.33 \mathrm{a}$ \\
$36 \%$ & $33.33 \mathrm{a}$ \\
\hline
\end{tabular}

Flavonoid yang terkandung dalam ekstrak ketapang bersifat toksik dengan kontak langsung terhadap larva. Senyawa flavonoid masuk ke dalam mulut serangga dan menyerang pernafasan serta menyebabkan kerusakan spirakel sehingga terjadinya gangguan pada sistem pernafasan larva yang kemudian menyebabkan kematian (Dinata, 2008). 
Menurut Batubara, dkk. (2012) fenolik sebagai larvasida bekerja dengan cara menekan konsumsi makan karena mengandung rasa pahit sehingga menyebabkan terhambat dan berkurangnya selera makan pada larva. Sejalan dengan penelitian Herminanto dan Sumarsono (2004) yang menyatakan bahwa larva yang telah berhenti makan akan menyebabkan perubahan panjang larva, bobot berkurang dan tubuh larva berubah menjadi cokelat kehitaman. Pemberian ekstrak daun ketapang menyebabkan beberapa larva yang mati mengeluarkan bau tidak sedap yang berasal dari cairan yang dikeluarkan larva. Pada penelitian juga ditemukan adanya larva yang mati dengan keadaan perut hancur.

\section{Mortalitas Total}

Mortalitas menunjukkan tingkat kemampuan atau jumlah kematian hama yang disebabkan oleh insektisida dari EDK yang diujikan pada perlakuan terhadap Spodoptera litura. Mortalitas ekstrak menunjukkan tingkat toksik yang terdapat dalam larutan tersebut. Pengamatan dilakukan di laboratorium selama 6 hari dengan cara menghitung jumlah larva yang mati setiap harinya. Hasil sidik ragam mortalitas total EDK terhadap Spodoptera litura dapat dilihat pada Tabel 3.

Tabel 3. Mortalitas Total.

\begin{tabular}{cc}
\hline Perlakuan & Mortalitas Harian(\%) \\
\hline Kontrol & $0.00 \mathrm{~b}$ \\
$9 \%$ EDK & $100.00 \mathrm{a}$ \\
$18 \%$ EDK & $100.00 \mathrm{a}$ \\
$27 \%$ EDK & $93.33 \mathrm{a}$ \\
$36 \%$ EDK & $93.33 \mathrm{a}$ \\
\hline
\end{tabular}

Mortalitas disebabkan banyak tidaknya kandung kimia yang bersifat racun pada ekstrak daun ketapang. Sejalan dengan hasil penelitian Rusdy (2010) yang menyatakan bahwa semakin banyak atau pekatnya suatu bahan kimia akan semakin banyak bahan aktif yang terkandung maka semakin besar pengaruhnya terhadap mortalitas larva. Senyawa yang terdapat pada daun ketapang yang bersifat racun perut yaitu tanin, saponin dan flavonoid, alkaloid dan fenolik.

Fenolik merupakan senyawa tertinggi yang terdapat pada daun ketapang. Sejalan dengan pendapat Mardiana (2009), bahwa senyawa fenolik yang merupakan polimerasi polifenol sederhana. Senyawa ini ditemukan hampir didalam dua grup yakni tanin yang dapat dihidrolisis dan tannin kondensasi.
Penggunaan senyawa fenolik dapat menyebabkan terjadinya penyerapan air pada tubuh organisme sehingga dapat mematikan organisme, karena tubuh organisme kekurangan air. Selain itu senyawa flavanoid yang dapat menurunkan laju reaksi kimia sehingga mengganggu mekanisme energi dalam mitokondria dengan menghambat sistem pengangkutan elektron.

\section{Toksisitas $\mathrm{LC}_{50}$}

Toksisitas EDK terhadap kematian Spodoptera litura setelah aplikasi pengaplikasian didapatkan dari jumlah larva uji yang mati selama penelitian. Data hasil penelitian selanjutnya dianalisis probit menggunakan software Minitab 16 Statistic Software for windows untuk mendapatkan nilai toksisitas $\mathrm{LC}_{50}$. Hasil analis probit toksisitas larva disajikan pada Gambar 1.

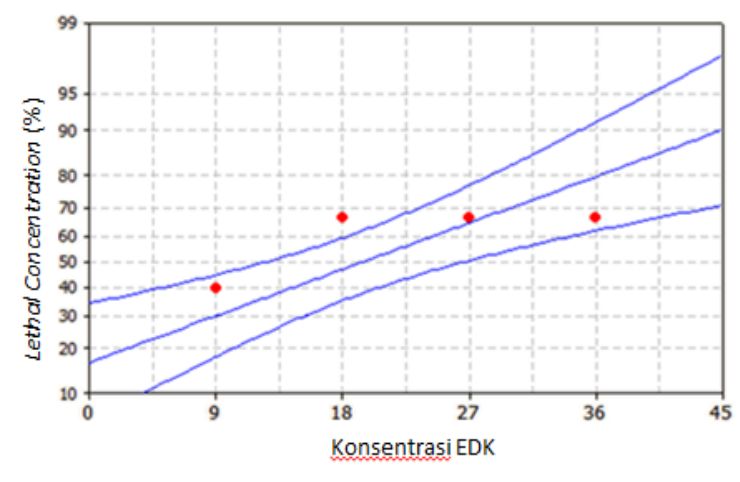

Gambar 1. Hasil Analis Probit Toksisitas Larva.

Nilai $\mathrm{LC}_{50}$ hasil analisis probit pada konsentrasi yang digunakann dalam penelitian yaitu kontrol, 9\%, 18\%, 27\% dan 36\%. Pada konsentrasi perlakuan kontrol sampai perlakuan $36 \%$ didapatkan persentase kematian Spodoptera litura berturut-turut sebesar 0\%, $40 \%, 66.7 \%$, 66.7\% dan 66.67\%. Hasil analisis toksisitas $\mathrm{LC}_{50}$ menunjukkan bahwa Lethal Concentration atau konsentrasi mematikan $50 \%$ dari populasi uji coba terdapat pada konsentrasi $19.6 \%$ EDK. Menurut Djojosumarto (2000), toksisitas atau daya racun pestisida adalah sifat bawaan pestisida yang menggambarkan potensi pestisida tersebut dapat mengakibatkan kematian langsung pada hewan tingkat tinggi. Menurut Suparjo (2008), saponin mempunyai efek antimikroba, zat penghambat jamur dan melindungi tanaman dari serangga. Senyawa saponin bersifat sebagai racun perut dengan menurunkan tegangan permukaan selaput kulit 
larva serta mampu mengikat sterol dalam pencernaan makanan.

\section{Larva Jadi Pupa (\%)}

Spodoptera litura memiliki siklus hidup yang terdiri antara telur, larva (instar 1-5), pupa dan imago (ngengat) yang berlangsung sekitar 30-60 hari. Larva yang digunakan dalam penelitian adalah instar 3 dengan kisaran waktu 5 hari. Hasil analisis sidik ragam persentase perubahan larva menjadi pupa selama dilaksanakannya penelitian disajikan pada Tabel 4.

Tabel 4. Persentase Larva Menjadi Pupa.

\begin{tabular}{cc}
\hline Perlakuan & Persentase Larva Menjadi Pupa \\
\hline Kontrol & $4.45 \mathrm{a}$ \\
$9 \%$ & $0.00 \mathrm{~b}$ \\
$18 \%$ & $0.00 \mathrm{~b}$ \\
$27 \%$ & $0.00 \mathrm{~b}$ \\
$36 \%$ & $0.00 \mathrm{~b}$ \\
\hline
\end{tabular}

Berdasarkan tabel sidik ragam di atas menjelaskan bahwa pada perlakuan kontrol terjadi perubahan larva menjadi pupa sebanyak $4.45 \%$. Perlakuan kontrol memiliki pengaruh nyata dibanding dengan perlakuan lainnya yang menunjukkan hasil $0.00 \%$ atau tidak adanya larva yang berubah menjadi pupa. Pada perlakuan lainnya tidak terjadi perubahan dikarenakan adanya senyawa aktif pada ekstrak yang bersifat racun bagi larva sehingga menghambat terjadinya pembentukan pupa.

Menurut Wigglesworth (1974 dalam Baideng 2016), menjelang akhir stadia larva banyak cadangan glikogen yang terakumulasi untuk pembentukan kokon, sehingga aktifitas biokimia digunakan untuk membentuk senyawa tersebut yang mengakibatkan aktifitas metabolisme untuk menetralisir racun dalam tubuh larva menurun. Semakin tinggi konsentrasi ekstrak maka semakin tinggi pula daya racun yang terkandung di dalamnya. EDK mempunyai kandungan senyawa saponin yang tinggi sehingga menyebabkan penghambatan perkembangan larva instar sehingga mengalami gangguan saat ekdisis. Ekdisis atau ganti kulit diperlukan serangga tidak hanya untuk tumbuh melainkan juga untuk mencapai tahap dewa sehingga dapat berkembang biak (Yunita dkk, 2009).

\section{KESIMPULAN}

Berdasarkan hasil penelitian disimpulkan bahwa konsentrasi efektif adalah konsentrasi 18\% EDK.

\section{DAFTAR PUSTAKA}

Batubara, I., S. Kotsuka, H. Yamauchi, T. Kuspradini, Mitsunaga, dan L. K. Darusman. 2012. TNF-a Production Inhibitory Activity, Phenolic, Flavonoid Ada Tannin Contents Of Selected Indonesian Medicinal Plants. Research Journal of Medicinal Plant, 6(6): 406415.

Djojosumarto, P. 2008. Teknik Aplikasi Pestisida. Kanisius, Yogyakarta.

Irnawati, P. dan P. Nita. 2012. Kajian Ekstraksi Tanin Dari Daun Ketapang (Terminalia catappa Linn). Online pada: https://textid.123dok.com/docu ment/y96998rykajian-ekstraksi-tanindari-daunketapangterminaliacatappalinn.html.

Kardinan Agus. 2002. Pestisida Nabati, Ramuan dan Aplikasinya. Agromedia Pustaka, Jakarta.

Mardiana, L. 2009. Mencegah dan Mengobati Kanker pada Wanita dengan Tanaman Obat. Penebar Swadaya, Jakarta.

Marwoto \& Suharsono. 2008. Strategi dan Komponen Teknologi Pengendalian Ulat Garayak (Spodoptera litura) pada Tanaman Kacang Kedelai. Jurnal Litbang Pertanian, 27(4): 131-136.

Rusdy, A. 2010. Pengaruh Pemberian Ekstrak Bawang Putih terhadap Mortalitas Keong Mas. Jurnal Floratek, 5(2): 172180.

Samsudin.2008. Pengendalian Hama dengan Insektisida Botani. Lembaga Pertanian Sehat.

Saputra, D. R., T. Hadiastono, A. Afandhi, dan Bedjo. 2015. Sinergisme Spodoptera litura Nuclear Polyhedrosis Virus JTM 97C (SINPV-JTM 97C) Dengan Ekstrak Biji Sirsak (Annona muricata L.) Dalam Pengendalian Helicoverpa armigera Hubner (Lepidoptera: Noctuidae) Pada Tanaman Kedelai (Glycine max L.) Di Laboratorium. Jurnal HPT, 3(3):

Sinaga, R. 2009. Uji Efektivitas Pestisida Nabati terhadap Hama Spodoptera litura (Lepidoptera: Noctuidae) pada Tanaman Tembakau (Nicotiana tabaccum L.). 
Skripsi (Tidak Dipublikasikan). Fakultas Pertanian, Universitas Sumatera Utara, Medan.

Sumihe, G., R. J. Max Runtuwene dan J. A. Rorong. 2014. Analisis Fitokimia dan Penentuan Nulai LC50 Ekstrak Metanol Daun Liwas. Jurnal Ilmiah Sains. Suparjo. 2008. Saponin. Jurnal Laboratorium Makanan Ternak, 14(2): 125-128.

Tohir, A. M. (2010). Teknik Ekstraksi dan Aplikasi Beberapa Pestisida Nabati Untuk Menurunkan Palatabilitas Ulat Grayak (Spodoptera litura Fabr.) di Laboratorium. Buletin Teknik Pertanian. Yanuwiadi, B., Amin Setyo Leksono, Hiasinta Guruh H., M. Fathoni dan Bedjo. 2013. Potensi Ekstrak Daun Sirsak, Biji Sirsak dan Biji Mahoni untuk Pengendalian Ulat Grayak (Spodoptera litura). Jurnal Natural B, 2(1): 88-93. 